\title{
E-WOM AND PROMOTION INFLUENCE TOWARDS DECISIONS TO STAY AT MALANG RAYA HOTEL
}

\author{
Desi Wardani ${ }^{(1) *}$, Rulli Krisnanda ${ }^{(2)}$ \\ (1)(2) Program Studi D3 Perhotelan \\ Universitas Merdeka Malang \\ desiwrd@gmail.com*,rulli.krisnanda7@gmail.com \\ Submitted : 25 January $2021 \quad$ Revised: 8 March 2021 \\ Accepted : 18 March 2021
}

\begin{abstract}
This study aims to determine and analyze the influence of variables from e-WOM and promotion on decisions to stay at hotels throughout Malang. The population used is customers or consumers who have stayed at the hotel and who have the potential to stay at the hotel. This research uses quantitative research with a survey method through a questionnaire. The number of samples in this study was 100 respondents. This sample was taken in the period of December 2020. The analysis technique of this research used multiple linear regression. The test results of this study indicate that each of the e-WOM and Promotion variables has a positive and significant effect on the Decision to Stay at Hotels in Malang Raya. This test shows that the e-WOM variable has a dominant influence on the decision to stay overnight with the results of the beta statistical value in the t-test that is greater than the promotion variable. This condition shows that the better the e-WOM that is disseminated and an innovative promotional strategy will increase consumer decisions to stay at hotels throughout Malang. This study is different from other studies because in this study, we put the object of the research into all hotels in Malang, with a survey that was distributed to hotel customers who had stayed in several different hotels.
\end{abstract}

Keywords: e-WOM, promotion, Decision to stay overnight

\section{INTRODUCTION}

Tourism is a sector that has an important position for society. If we took a glance at the tourism development target in 2015-2019, the National Planning Development Agency targets the contribution of the tourism sector to GDP to reach 8 percent with a target of 275 million domestic tourist visits in 2019. The potential for tourism development is quite large, especially when referring to tourism growth performance data. According to the World Trade Tourism Council (WTTC), which places Indonesia in the ninth-largest rank in the world. This is what causes the development of the lodging or hotel business to increase every year in Indonesia. Competition in the lodging services business is very tight, seen from the very close distance between one hotel and another.

This makes the management of lodging services companies compete to make strategies to increase sales of their lodging services. Various aspects can influence consumer decisions to stay at certain hotels, including aspects of price, 
service, facilities, location, promotions and so on.

This business usually increases during the holidays because many tourists will use lodging services or hotels as a temporary resting place. I chose Malang as a research object because in our opinion, Malang has the potential to become a tourist spot and hotel development, especially in the southern part of Malang, which is famous for its beaches, besides that Malang is very suitable for research location. A hotel is a place of lodging that provides facilities to support the comfort of guests or consumers and has rental rates set by management. The integration of these elements will be the key to the success of a service company to improve performance, build customer satisfaction through satisfying facilities. Not only that, in the current era of globalization, the internet has become a trend for many consumers before making the purchase process.

Many people do their research before making a visit or staying at a hotel. There are also those who are looking for any interesting promotions offered by hotels so that prospective visitors are interested in staying at the hotel. Peterson and Merino (2003) say that consumers tend to seek information about products or services to be purchased on the internet. According to Hennig-Thurau and Walsh (2004), the internet provides various ways to get information related to products or services from other consumers. Jones (2010) defines social networking sites as public media where users can write, store and publish information online. Goldsmith and Horowitz (2006) state that internet users have changed the way consumers communicate and share opinions or reviews about products or services that have been consumed. The process of communication between consumers via the internet is known as the Electronic Word of Mouth (e-WOM). Gruen (2006) defines e-WOM as a communication medium to share information about a product or service that has been consumed between consumers who do not know each other and have met before.

Based on the background described above, the problem formulations that can be identified are. How is the effect of eWOM on decisions to stay overnight? How is the effect of promotion on decisions to stay overnight? Which variable has the dominant influence on decisions to stay overnight?

The purpose of this study is to determine the effect of e-WOM on the decision to stay at the hotel, to determine the effect of promotion on the decision to stay at the hotel, to determine the variables that affect the decision to stay at the hotel.

\section{LITERATURE REVIEW e-WOM (Electronic Word-of-Mouth)}

Thurau, Gwinner, Walsh and Gremler (2004) define e-WOM as positive or negative statements made by potential customers, or previous customers about a product or company where this information is available to many people and institutions via the internet. Kietzman and Canhoto (2013) state that e-WOM is a statement or opinion from consumers regarding a product, service, brand, or company that is shared with other consumers via the internet. E-WOM has a major impact on consumer purchasing behavior. Recommendations from trusted friends, associates, and other consumers have the potential to be trusted more than from commercial sources, such as advertisements and sales people. For the most part, Word of Mouth occurs naturally, consumers start by talking about a brand that they use to others (Kotler \& Amstrong, 2012: 139).

Dimensions of e-WOM According to Bambauer-Sachse and Mangold (2011), measuring e-WOM from three aspects, namely:

1. General persuasiveness 
- Online product reviews have an impact on purchasing decisions.

- Before making a purchase decision, look at product reviews on websites to find out the opinions of other consumers.

2. General credibility

- Trustworthy online product reviews.

- Trust the online reviews of products provided by other consumers.

3. Susceptibility to online product reviews

- Read online reviews of products from other consumers to find out what products or brands make a good impression on others.

- Buy the right product or brand by reading online product reviews from other consumers.

- Consult with other consumers about online reviews of the product to help in choosing the right product or brand.

- Gather information from online product reviews before purchasing a particular product or brand.

The dimensions of e-WOM according to Roles of Product Involvement and Brand Image divide E-WOM into 3, namely:

1. e-WOM Quality refers to the persuasive power of comments embedded in information messages (Bhattacherjee, 2006). Consumer purchasing decisions can be based on several criteria or requirements that meet their needs and to determine their willingness to buy will be based on their perceived quality of information they receive (Cheung, 2012). Therefore, it is important to determine consumers perceptions of information quality as an element for assessing their potential purchasing decisions.

2. e-WOM Quantity refers to the number of posted comments (Cheung and Thadani, 2010). The popularity of a product is determined by the quantity of online comments because it is considered to represent the product's market performance (Chevalier and Mayzlin, 2006). Consumers also need references to strengthen their confidence to reduce feelings of mistakes or risks when shopping and the quantity of comments online represents the product's popularity and importance. In other words, consumers may feel that more reviews represent the high popularity of the product and its importance (Lee, 2009).

3. Sender's Expertise is required training and experience and is domain specific. On the other hand, expertise can be seen as "authority," "competence," and "expertise" (Hung and Cheng 2006). It is considered that the expertise of senders when they make comments in consumer reviews will attract users to adopt the information and make a purchase decision.

\section{Promotion}

According to Efrianto, (2016) Promotion is a means of various incentives that are carried out to meet targets in the short term and are designed to stimulate buyers of certain products faster or stronger by consumers or traders everywhere. Promotion is not a single tool but rather a mix of several tools. Ideally, under the concept of integrated marketing communications, a company will carefully coordinate these promotion elements to engage customers and build a clear, consistent, and compelling message about the organization and its brands, (Kotler and Amstrong, 2016: 444) means that promotion is not a single tool but a mixed tool ideally within the concept of unified marketing communications, companies take great care to coordinate promotional elements in engaging customers and building clear, consistent, and compelling messages about the organization and its brands. However, according to Hermawan, (2012: 54), there are 6 channels in communication mix such as advertising, sales promotion, publicity, personal selling, direct marketing, and experiences.

\section{The Purpose of Promotion}

The main objective of sales promotion is to increase sales of a product by creating demand, namely consumer 
demand, and trade demand. Promotion enhances the performance of intermediaries and acts as a supplement to advertising and personal selling. Promotion can help a company achieve the following goals:

1. The basic purpose of promotion is to spread information to potential customers.

2. Sellers use incentive-type promotions to attract new customers, to reward loyal customers and to increase the occasional user repurchase rate.

3. To encourage customers to try new products. A sales promotion generates a sales response that is faster than an advertisement.

4. Sales promotion is considered as a special sales effort to accelerate sales.

5. To win competitor's promotional activities.

\section{RESEARCH METHOD \\ Types of research}

This research uses quantitative research with a survey method through a questionnaire. Quantitative research is research that can be calculated through statistical methods with data in the form of numbers, while Arikunto (2010: 312) states that surveys are one type of research that is often carried out by researchers in the fields of sociology, business, politics, government, and education. Researchers use hotels located in Malang Raya as objects in this study. Researchers have determined to use primary data collected directly from research subjects. The research subjects used are customers or consumers who have stayed at the hotel and who have the potential to stay at the hotel.

\section{Analysis}

Multiple Linear Regression

According to Algifari (2015: 56), a regression model for analyzing or knowing the relationship of the influence of two or more independent variables on one dependent variable is called multiple regression analysis. Some calculation processes are not always good at analyzing the relationship between the affected variable (dependent variable) and the influencing variable (independent variable). The dependent variable used is the decision to stay overnight (Y). Meanwhile, there are two independent variables that can affect the dependent variable, namely e-WOM (X1) and promotion (X2). So that to find out the hypothesis test that has been formulated previously, the authors develop a multiple linear regression equation as follows:

$\mathrm{Y}=\alpha+\beta 1 \mathrm{X} 1+\beta 2 \mathrm{X} 2+\mathrm{e}$

Where:

$\mathrm{Y}=$ Decision to Stay

$\alpha=$ Constant

$\beta 1,2=$ Regression coefficient of each independent variable

$\mathrm{XI}=\mathrm{e}-\mathrm{WOM}$

$\mathrm{X} 2=$ Promotion

$\mathrm{e}=$ Standard Error

\section{Variables and Variable Operational Definitions}

The variable is an indicator of the object to be studied where the variable that affects is said to be an independent variable, while the variable that is affected is called the dependent variable, then all of these variables are tested and conclusions are drawn (Algifari, 2015: 1). The operational definition of a variable is a definition given to a variable by giving meaning or specifying activities or justifying an operation to measure the variable. The following is the operational definition of each variable used in this study:

\section{A. E-Wom}

e-WOM has a definition as a communication medium to share information about a product or service that has been consumed between consumers who do not know each other and have met before (Gruen, 2006). According to Sen and Leman (2008), the main 
Desi Wardani, Rulli Krisnanda: E-WOM and Promotion Influence Towards Decision to Stay at Malang Raya Hotel

factor of e-WOM is that the information sources are independent. This means that the eWOM information source is not tied to a particular company and does not benefit any company. Therefore, the communication process through e-WOM does not trust the source of information that comes from the company.

\section{B. Promotion}

Promotion is an activity carried out by marketers to stimulate or stimulate prospective customers to immediately determine purchase decisions. The 5 out of 6 promotional indicators put forward by (Hermawan, 2012: 54) are used as a measuring tool in this study, including: 1) Advertising, 2) Sales Promotion, 3) Personal Selling, 4) Direct Marketing, 5) Events and Experience.

\section{Overnight Decision}

The decision to stay is an act in making a decision to choose an inn or hotel to be used as a temporary residence requiring a little stimulus to speed up purchasing decisions. The five indicators put forward by (Tjiptono and Diana, 2016: 60) include: 1) Identification of Needs, 2) Search for Information, 3) Evaluation of Alternatives, 4) Purchase Decisions, 5) Evaluation of Retirement.

\section{RESULTS AND DISCUSSION \\ Multiple Linear Regression Analysis}

Multiple linear regression is a regression equation used to analyze the influence between independent variables with the decision to stay overnight as the dependent variable. The data in this study were managed using the SPSS 20 program on a computer as a tool.

Tabel 1 Results of Multiple Linear

Regression Analysis Coefficients

\begin{tabular}{ccc}
\hline Model & $\begin{array}{c}\text { Unstandardized } \\
\text { Coefficients }\end{array}$ & $\begin{array}{c}\text { Standardized } \\
\text { Coefficients }\end{array}$ \\
\hline B & Std. Error & Beta \\
\hline & (Constant) $\quad 2.348$ & 1.989
\end{tabular}

\begin{tabular}{llll}
\hline $\mathrm{X} 1$ & .509 & .087 & .502 \\
\hline $\mathrm{X} 2$ & .282 & .097 & .252 \\
\hline $\mathrm{a}$ & $\mathrm{Dependen}$ \\
\hline
\end{tabular}

a. Dependent Variable: $\mathrm{Y}$

Based on Table 1 above, the multiple linear regression equation is obtained as follows:

$\mathrm{Y}=2,348+0,509 \mathrm{X} 1+0,282 \mathrm{X} 2+\mathrm{e}$

The multiple linear regression equation above, can be explained as follows:

1). Constant (a), from the multiple linear regression equation above, the positive constant is the value of 2.348. This means that if the independent variable in this study is assumed to be zero, then the decision to stay at the hotel is worth 2,348. 2). Regression Coefficient X1 (BX1), eWOM regression coefficient (X1), from the multiple linear regression equation shows a result of 0.509 , which indicates that e-WOM (X1) has a positive effect on the decision to stay at a hotel.

This means that if the e-WOM variable increases by 1 unit, the stay decision variable (Y) will increase by 0.509 if the promotion variable (X2) is assumed to have a fixed value. Regression coefficient $\mathrm{X} 2 \quad(\mathrm{BX} 2)$, promotion regression coefficient (X2), from the multiple linear regression equation shows a result of 0.282 , which indicates that promotion (X2) has a positive effect on the decision to stay (Y) at the hotel. This means that if the promotion variable has an increase of 1 unit, then the stay decision variable will also increase by 0.282 if the e-WOM variable is assumed to have a fixed value.

\section{Hypothesis Test (t-test)}



at Malang Raya Hotel

Hypothesis testing (t-test) was conducted to test the influence of each independent variable consisting of e-WOM (X1) and promotion (X2) on the dependent

\begin{tabular}{lllll}
\hline Model & $\mathbf{t}$ & Sig. & $(\boldsymbol{\alpha})$ & $\begin{array}{l}\text { Explana- } \\
\text { tion }\end{array}$ \\
\hline $\mathrm{X} 1$ & (Constant) & 1.181 & .241 & .05 \\
\hline $\mathrm{X} 2$ & 2.823 & .000 & .05 & $\begin{array}{l}\text { Influenced } \\
\text { significantly }\end{array}$ \\
\hline
\end{tabular}

Based on the results shown in the table, the value of hypothesis testing ( $\mathrm{t}-$ test) on each variable, namely e-WOM (X1) and promotion (X2) on the dependent variable, namely the decision to stay overnight (Y) can be explained as follows: 1). e- WOM (X1), the results of hypothesis testing (t-test) of the effect of the e-WOM variable $(\mathrm{X} 1)$ on the decision to stay $(\mathrm{Y})$ show that the tcount is 5.823 with a significance of $0.000<0.05$, it can be concluded that $\mathrm{HO}$ is rejected. So, partially e-WOM (X1) has a positive and significant effect on the decision to stay overnight (Y).

2). Promotion (X2), the results of hypothesis testing (t-test) the effect of the promotion variable $(\mathrm{X} 2)$ on the decision to stay (Y) shows that the tcount is 2.919 with a significance of $0.004<0.05$, it can be concluded that $\mathrm{HO}$ is rejected. So, partially promotion (X2) has a positive and significant effect on the decision to stay overnight $(\mathrm{Y})$.

\section{CONCLUSION}

There are three conclusions as a result of this study which can be described below:

The test results show that the eWOM variable has a positive and significant effect on the decision to stay overnight.

Promotion has a positive and significant effect on the decision to stay overnight. The promotion by the hotel is quite influential on the consumer's decision variable, namely the decision to stay overnight $(\mathrm{Y})$. This test is done partially with a significance $(\alpha)$ of $5 \%$.

to stay overnight. The more often the promotion is carried out and given to potential customers, the more consumers will decide to stay at the hotel.

E-WOM has a dominant influence on the decision to stay overnight which is shown in the beta statistical value in the ttest.

The suggestions that the author can share in this scientific article such as to increase visitors, the hotel is expected to increase access to information, interact with online customers, get lots of positive reviews from visitors, and respond to online reviews well. Also to increase hotel visitors, hotel management should often make promotional promotions that attract visitors and evaluate promotional strategies.

\section{ACKNOWLEDGEMENT}

This scientific article cannot be completed as expected without the help and support of various parties. Therefore I would like to thank profusely to:

Allah SWT who has given energy and thoughts so as to complete this report on time, my parents who have helped a lot in terms of morale and material, Mr. Rulli Krisnanda, S.Tr.Par, MM as the supervisor who has taken his time and thoughts to help me revise scientific articles.

\section{REFERENCES}

A. Diana. (2016). Pemasaran: Esensi dan Aplikasi. Andi Offset. Yogyakarta.

Agus, Hermawan. (2012). Komunikasi Pemasaran. Jakarta: Erlangga.

Algifari. (2015). Analisis Regresi Untuk Bisnis dan Ekonomi. Edisi Ketiga. BPFE. Yogyakarta 
Desi Wardani, Rulli Krisnanda: E-WOM and Promotion Influence Towards Decision to Stay at Malang Raya Hotel

Arikunto, S. (2010). Prosedur Penelitian Suatu Pendekatan Praktek. PT. Rineka Cipta. Jakarta

Armstrong, G \& Kotler, p.(2005). Marketing an introduction. Toronto: Prentice- Hall.

Bambauer-Sachse, S. \& Mangold, S. (2011). Brand equity dilution through negative online word-of mouth communication. Journal of Retailing and Consumer Services. 18. 38-45 Brynjolfsson, E., \& Smith, M. D. (2010). Frictionless commerce? A comparison. MIT Sloan School of Management, 50 Memorial Drive, Cambridge, Massachusetts 02139

Bhattacherjee, A., \& Sanford, C. (2006). Influence processes for information technology acceptance: An elaboration likelihood model. MIS quarterly, 805825.

Cheung, C. M \& Thandani, D. R. (2012) The impact of electronic word of mouth communication: A literature analysis and integrative model, Journal of Decision Support Systems, 54(1). 461-470.

Chevalier, J. A \& Mayzlin, D (2006). The effect of word of mouth on sales: online book reviews, Journal of Marketing Research, 43(3), 345-354.

Efrianto, A. (2016). Pengaruh Harga, Lokasi, Promosi, dan Layanan Terhadap Keputusan Menginap di Hotel Alana Surabaya. Jurnal Ilmu dan Riset Ekonomi. 5.(9): 1-15

Goldsmith, R. E \& Horowitz, D. (2006). Measuring motivations for online opinion seeking, Journal of Interactive Advertising, 6(2),3-14.

Gruen,T. W., Osmonbekov, T., Czaplewski, A. J. (2006). e-WOM: the impact of customer-to-customer online know-how exchange on customer value and loyalty, Journal of Business Research, 59(4), 449-456.

Hennig-Thurau, T., Gwinner, K. P., Walsh, G., \& Gremler, D. D. (2004).
Electronic word-of-mouth via consumer-opinion platforms: what motivates consumers to articulate themselves on the internet?. Journal of interactive marketing, 18(1), 38-52.

Hung L, Cheng W. (2012) "The Relationship between Affective and Continuance Organization Commitment" Jurnal of Asian Economic and Social Society. No.5, Vol.2. HWA Hsia Institute of Technology. Taiwan

Jones, B.(2010). Entrepreneurial marketing and the web 2.0 interface, Journal of Research in Marketing and Entrepreneurship, 12(2), 143-152.

Kietzman, H.J \& Canhoto, A. (2013). Bittersweet! Understanding and managing electronic word of mouth . Journal of Public Affairs, 13(2), 146159.

Kotler, P, and K. L. Keller. (2012). Marketing Management. Fourteen Edition. Prentice-Hall. New Jersey and G. Amstrong. 2016. Principles of Marketing. Sixteenth Volume. Seventeenth Edition. Pearson Education. USA

Lee, S. et al. (2009). A Review of Casebased Learning Practices in an Online MBA Program: A Program-level Case Study. Educational Technology \& Society, Vol. 12 (3).

Peterson, R.A., \& Merino, M.C. (2003). Consumer information search behavior and the Internet. Psychology \& Marketing, 20(2), 99-121.

Sen, S. and Lerman, D. (2007), Why are you telling me this? An examination into negative consumer reviews on the web, Journal of Interactive Marketing, Vol. 21 No. 4, pp. 76-94.

Tjiptono, F \& Diana. (2014). Pemasaran Jasa, Prinsip, Penerapan dan Penelitian. Andi Offset. Yogyakarta 
38 - JITHOR Vol.4, No.6, April 2021 - eISSN : 2654-4687 pISSN : 2654-3894 